i když fakticky pokrývá mnohem širší okruh problematiky. Polská rusistika se zde ukázala ve velmi dobrém světle: svými názory, koncepcemi, ale hlavně schopností soustředit kolem svých okruhů badatele z jiných zemí. A také to, že emigraci nelze brát jako jev výlučný, ale jako výslednici řady okolností, které se do ní promítají.

Ivo Pospišil

\title{
Literatura:
}

DĄBROWSKA, M., GŁUSZKOWSKI, P. (eds) (2018): Aleksander Solżenicyn i rosyjska emigracja. Warszawa-Toruń, 2018.

LAKŠIN, V. (1991): Solženicyn a ti druzí. Překlad I. Pospíšil. Demokrat, 6. 3. 1991.

POSPÍŠIL, I. (1992a): „Archipelag GULAG“ i russkaja tradicija „preodolenija literatury“. In: KOVAČIČOVÁ, O. (ed.): A. I. Solženicyn v kontexte európskej literatúry: sborník príspevkov zo sympózia o tvorbe A. I. Solženicyna, Bratislava 1992, s. 69-77.

POSPÍŠIL, I. (1992b): Od Bachtina k Solženicynovi. Srovnávací studie. Boskovice, 1992. POSPÍŠIL, I. (1993): Emigracja i tamizdat. Skice o wspólczesnej prozie rosyjskiej. Red. Lucjan Suchanek. Kraków 1993. SPFFBU, XLVI, D 44, 1997, s. 156-158.

POSPÍŠIL, I. (1994): Alexandr Solženicyn. Tematická jednotka pro střední školy. Brno, 1994.

POSPÍŠIL, I. (1999): Alexandr Solženicyn: Rusko v troskách (Ukázka ze stejnojmenné knihy, naklad. „Russkij put'“, Moskva 1998). HOST 15, 1999, č. 7, s. 42-47.

POSPÍŠIL, I. (200o): Poláci se dívají na Rusko (Lucjan Suchanek - Alexandr Zinovjev). HOST 16, 2000, č. 7, s. 44-46.

\section{Od metodiky výuky literatury k teorii, eseji a interview: invenční texty Iriny Kalusové}

КАЛУС, И.: Современная русская литература: статьи, эссе, интервью. Москва: Издательство «Согласие», 2017. ISBN 978-5-90670-977-6.

Šéfredaktorka moskevského internetového časopisu Parus [Russkij... 2018], odkud také pocházejí texty tohoto svazku, Irina Kalusová se provdala za Slováka Petra Kaluse, s nímž žije stř́idavě v Rusku (většinou) a na západním Slovensku; osobní prríčina 
ji vedla a vede $\mathrm{k}$ studiu slovenské a české literatury, takže je naděje, že se ruská literatura jako její doména postupně ocitne na výraznější srovnávací ploše. Přítomný svazek představuje vícedílný, ale přesto hodnotově a metodologicky celistvý koncept ruské literatury prezentovaný také žánrovým různohlasím - kritické a teoretické reflexe, eseje a interview. Na počátku stojí pedagogické a metodické úvahy, následuje průřez některými díly některých ruských autorů současnosti, poté analýzy metakritiky, pokračuje teoretická reflexe př́tele Michaila Bachtina (1895-1975) a editora jeho díla Vadima Kožinova (1930-2001), následují dva eseje a soubor rozhovorů s literárními kritiky, spisovateli a literárními vědci. Svazek ukazuje, že si musíme stále více zvykat na pestrost prezentace literatury v jejím kritickém rámci, že již nelze jako nevědecké odmítat žánry hraniční (esej, rozhovor, reportáž, memoárové texty), o nichž jsme nejednou psali, počínaje již 8o. léty 20. století a které jsou v dnešní době jednoznačně vůdčími nebo/a nejvlivnějšími: ${ }^{1}$ jde o různé způsoby poznávání a také o různé, užitečné komunikační plochy. I k tomu je však třeba přistupovat s mírou, což se Kalusové vcelku daří.

To, co je v osobitém metodickém úvodu Iriny Kalusové podstatné, je důraz na diskusní formu výuky a na současnou literaturu v širokém slova smyslu. Diskuse má přirozeně zahrnovat tvůrce proudící literatury („tekuščaja literatura“), živého literárního procesu, tj. spisovatele a jejich kritiky. Toto musí vzbudit u českého literárního vědce shovívavý úsměv: jak to lze vše realizovat při faktické neexistenci normálního literárního života, který - pokud vůbec v běžné podobě existuje - je rozbitý na desítky diskursů, $\mathrm{v}$ nichž už je v době globalizace narušena globalita literární komunikace, když pomineme osobní útoky nebo naopak ladění těch, kteří si vyhovují především svými ideologickými nebo jen úzce osobními zájmy? Nevím, jak to funguje v ruském literárním prostoru, ale domníval bych se, že je to asi podobné, byt nikoli ve všem.

Soubor studií a glos o současné ruské literatuře dává vědět, že se autorka - stejně tak je ostatně koncipován internetový časopis Parus, jehož je šéfredaktorkou - je orientována spíše na ruskost literatury, na její konzervativnější, tradicionalističtější podobu, možná blízkou někdejší linii časopisu Naš sovremennik zhruba od 6o.-70. let 20. století, nacházející své kořeny v ruské konzervativní a religiózní filozofii 19. a počátku 20. století. Je zajímavé, že se $\mathrm{v}$ epicentru takto zaměřené autorky neobjevil autor takového významu a zvláštní politické a estetické orientace, jakým je Jurij Bondarev, kromě všeobecně známých, leč zcela nebo zpola zapomenutých románů sovětského období, autor románů Pokušení (Iskušenije, 1992), Neodporování (Neprotivlenije, 1996), Bermudský trojúhelník (1999) a Bez milosrdenství (Bez

1 Viz některé naše studie a desítky zde neuvedených recenzí (jsou jich desítky) na dané téma [POSPÍŠIL 1984; POSPÍŠIL 1985b; POSPÍŠIL 2009; POSPÍŠIL 2015; POSPÍŠIL 2016]. 
miloserdija, 2004). ${ }^{2}$ Když si přečteme jména zmiňovaných spisovatelů, většinou prozaiků, vidíme, že to jsou právě ti, kteř́i jsou u nás bud’ zcela neznámí, nebo známí jen částečně. To potvrzuje můj po léta stálý názor, že naše představa ruské literatury je nejen neúplná, ale i deformovaná, tedy falešná, když už ne zfalšovaná. Jiná věc je, kde je estetická hodnota: ta se jistě nachází všude, nehledě na ideologická pnutí, a Irině Kalusové slouží ke cti, že se to snaží maximálně zohlednit, i když se zabývá autory a díly, která mají z tohoto hlediska zjevně kontroverzní ráz. Povídky Vaclava Michalského (nar. 1938 v Taganrogu) jsou žánrem, jímž začínal roku 1963 v daleké Machačkale, ale prosadil se spíše romány, mj. Balada o staré zbrani (Ballada o starom oružii, 1964), Sedmnáct levých střevíců (Semnadcat’ levych sapog, 1967), Tajné milosti (Tajnyje milosti, 1982) a zejména šestidílný román Jaro v Kartágu (Vesna v Karfagene, 2011). Nicméně povídky jsou útvarem, ke kterému se vrací, a to je právě doména Iriny Kalusové, která tu analyzuje povídku o neštastných osudech žen Svatební šaty č. 327 (Svadebnoje platje nomer 327, 1988). Dříve poněkud zasutá tvorba Vaclava Michalského se nyní ocitá více $\mathrm{v}$ popředí zájmu čtenářů a kritiky, možná také proto, že se výrazně odlišuje od módního proudění vycházejícího z modernistické a postmodernistické groteskní a absurdní metaliteratury, která byla - v protikladu k střední Evropě, o západní nemluvě - ruskou tradicí a sovětskou ideologií vždy odmítána: o to více se dostala do centra mediální pozornosti nyní. Právě konzervativní, tradiční literatura s národními kořeny je obrazem života „spodních 145 miliónü“ obyvatel Ruské federace.

Podobně je koncipovaná tvorba Leonida Borodina (1938-2011), sovětského disidenta, který ve věznicích SSSR strávil více než 11 let, především za činnost v nelegálních spolcích snažících se christianizovat veřejný život, nejvýraznějši v tehdejším Leningradě, kde byl aktivní v křestanském hnutí a souzen za protisovětskou agitaci. Později publikoval v tamizdatu, zejména ve Frankfurtu nad Mohanem (za to byl opět vězněn), na konci 8o. let 20. století se mu dostalo satisfakce; od roku 1990 působil v čelných funkcích v redakcích literárních časopisů. Jeho religiózní přesvědčení se výrazně promítá do jeho prózy, jež je tu analyzována (Pravidla hry, Pravila igry). Nutno dodat, že prózy L. Borodina, které v Rusku vzbudily pozornost literární kritiky, historie i teorie, český čtenář bohužel nezná, byt šlo o disidenta, které naše kulturní politika jinak preferuje [SERAFIMOVA 2013].

Ve studii Vysoká latka (Vysokaja planka) autorka kriticky posuzuje poezii Jevgenije Čekanova (nar. 1955). Národní kořeny zdůrazňuje ve svém díle další analyzovaný prozaik Anatolij Urvancev, letopisec uralského kozáctva. Mezi nimi klíčové místo

2 Viz např. naše stati a recenzi [POSPÍŠIL 2008b; POSPÍŠIL 2008c; POSPÍŠIL 2010]. Zkoumání „nové ruské ideologie“ podivuhodně mísící carské a sovětské tradice se věnujeme také v sérii statí a v recenzi s ukázkami o Juriji Bondarevovi (nar. 1924, stále žije!) a jeho románu Bermudský trojúhelník (1999) [POSPÍŠIL 2002a; POSPÍŠIL 2002b; POSPÍŠIL 2003; POSPÍŠIL 2008a]. 
zajímá dnes již slavný Jurij Poljakov (nar. 1954): autorka se zabývá jeho románem Houbový král (Gribnoj caŕ, 2005). Jak interpretace próz Alexeje Kotova, tak Kouzelné sklo Nikolaje Smirnova a vzpomínka na zesnulého Valentina Rasputina (1937-2015) ${ }^{3}$ mají jeden společný jmenovatel: návrat k tradici, k ruské klasice, hledání nové lidovosti a národních kořenů. Nezní to př́liš inovačně, experimentátorsky a objevně, ale taková už je podoba důležitého proudu dnešní ruské literatury, který má značně širokou základnu.

Ve studii Filozofická metakritika Jurije Pavlova se autorka zabývá jeho knihou, v níž na jedné straně hledá své blízké ruské literární kritiky, na druhé zase ostř̌e polemizuje s těmi, kteří podle něho chápou ruskou literaturu a roli kritiky chybně [PAVLOV 2010]. Autorka se $s$ jeho závěry v podstatě identifikuje a zase je to směr jeho i její, jenž je tradicionalistický, ruský, národní, hledající kořeny ruské národní literární kritiky nebo ji takto charakterizující, tedy podle tohoto klíče. Vůdčí linii této tradice jemu a jí představují V. Rozanov, M. Bachtin, V. Kožinov a M. Lobanov. Nejsou však jediní, které Pavlov chválí: dalšími jsou např́íklad S. Rassadin, I. Zolotusskij J. Selezňov, V. Bondarenko - a za nimi prosvítají siluety K. Aksakova, A. Chomjakova, N. Strachova a jiných se slavjanofilským pozadím. Naopak kritický je k metakritickým úvahám Dmitrije Bykova (nar. 1967). Je zřejmé, že rozpory jsou z mnoha prríčin, které tu nebudeme řešit, hluboké. Snaha spojit dědictví ruské klasiky, konkrétně její ikony A.S. Puškina, s dneškem vyplývá ze studie „Kdyby žil Puškin déle..." Název je citací slavného proslovu F. M. Dostojevského u příležitosti odhalení pomníku Puškina v Moskvě (1880). Autorka se však nespokojuje jen s vylíčením Puškina jako velkého smiřovatele, jakým se jeví $\mathrm{v}$ řeči Dostojevského, jenž se snažil smírit zapadniky a slavjanofily, ale jde ad fontes, zdůrazňujíc Puškinovo úsilí o krásu a celistvost jako základní atributy slovesného umění - jde tak ve stopách slavného článku básníkova př́tele Petra Vjazemského, který napsal deset let po Puškinově tragické smrti a v němž ukázal, jak se v jeho díle zrcadlí očistná, terapeutická síla umění. V pohledu na Puškina jako na silnou osobnost hledající a nacházející v umění základní existenciální dimenzi, sám důvod existence a sebezáchovné gesto jako zásadní oporu života se s autorkou shoduji. ${ }^{4}$

Vadim Kožinov (1930-2001) je právem autorčiným vzorem literárního kritika i teoretika, jemuž věnuje celý oddíl knihy počínaje jeho rustvím, jeho holistickým viděním artefaktu a konče jeho pojetím fašismu, náboženským pojetím ruské literatury, tradicí K.F. Golovina (1843-1913) jako kritika s možností aplikovat Kožinovovu metodologii v zkoumání díla F. M. Dostojevského (na př́íkladu Bratrů Karamazovových). I když jde někdy o názory značně kontroverzní, jejich hloubku

3 Viz naši stat [POSPÍŠIL 2018] a také naše dobové recenze [POSPÍŠIL 1983; POSPÍŠIL 1985a].

4 Viz naši knížku o Puškinovi [POSPÍšIL 1999]. 
a serióznost doloženou dlouholetým bádáním nelze apriorně odmítat. Základem úvah je křest’anství - jistě spíše $\mathrm{v}$ jeho osvícenské podobě - a jeho postupná likvidace jako základ jevů, které povedou k trvalým následkům pro evropskou civilizaci. $\mathrm{Na}$ ruské literatuře si Kožinov cenil - spolu s jeho obdivovatelkou - její náboženské báze, která je nepotlačitelná i ve 2o. století v době značně nepříznivé: důležitý je zde obrat k tzv. ,jiné realitě“, jež jako červená nit prochází vývojem nejen ruské literatury, ale představuje i „ruskou cestu“ (russkij put).

Esej o „geometrii současné literatury“ kritizuje snahu o exaktizaci literatury a umění a také umělecké kritiky jako velké nebezpečí. Téma Spisovatel a moc vidí v rámci duchovního prostoru: nejde jen o to stavět moc a spisovatele proti sobě, spíše se má hledat společný duchovní vektor a zde záleží na osobnostech politika a umělce. Je to poněkud jiné vidění než zautomatizovaný názor, že spisovatel má právo být soudcem druhých nebo že je bez bližšího zkoumání svědomím národa.

Debaty, které Irina Kalus vede s různými spisovateli a kritiky, se týkají povahy literatury, její hodnoty, morálky, role literární kritiky, filozofie literatury a schopnosti empatie a tolerance. První rozhovor vede s př́mo s Kalusovou Vjačeslav Bredněv jako se šéfredaktorkou časopisu Parus, kde se mimo jiné hodnotí toto periodikum a jeho role v ruském literárním životě. Další rozhovory vede Irina Kalusová, která se ptá Karla Šifnera, Ivana Jesaulova, Diany Kan, Anatolije Urvanceva, Vladimira Bondarenka, Jevgenije Čekanova, Alexeje Kotova, slovenské básnířky Zuzany Kuchárikové aj., mezi nimi i autora těchto řádků, kde jde hlavně o česko-ruské vztahy a českou recepci Ruska a ruské literatury.

Je zřejmé, že kniha se koncentruje kolem skupiny ideově a esteticky blízkých autorů, kteří jsou také pravidelnými přispěvateli časopisu Parus. Jsou to lidé vyjadřující ruskou národní a klasickou tradici, navazující na kořeny lidovosti, osobitého charakteru Ruska a jeho kultury, směrují $\mathrm{k}$ tomu, co ukazoval dávno před glasností a perestrojkou jejich předchůdce, právě zde často vzpomínaný Vadim Kožinov. Podstatou knihy je ukázat na určitý směr v ruské literatuře, jenž rozhodně není minoritní, naopak je silný a má své rozsáhlé čtenářstvo, poněkud však od 8o. let 20. století a zejména od konce minulého století zastíněn modernistickými a postmodernistickými proudy, jež se koncentrují na intelektuálního a městského recipienta. Ruská vesnice a ruské město jsou dvě entity, které se, jak se zdá, od sebe v posledních desetiletích ještě více vzdalují - a není to jen v Rusku; v menších zemích jde obvykle o hlavní město, které se stává mnohem více než dřive státem ve státě a to se projevuje silně nejen v politice, ale také v kultuře a literatuře. Současně se zde prezentuje antinomie centra a provincie, jinde se ř́ká centrum a region (přičemž regionem může být i Praha, ale většina tvrdí, že není).

Kalusová je z těch kritiků, kteří pomáhají objevovat literární talenty, budoucí velké autory i mimo centra, i když tito autoři poté do centra přicházejí. Rusko je chápáno jako celistvost, jejíž části se vzájemně obohacují. Dủležitou roli tu má také téma 
díla, nikoli uzavřené do bublin městské elity, naopak vnášející do ruské literatury syrové látky, jak bylo vždy zvykem, když ruská literatura skomírala vyčerpána jedním způsobem tvorby (charakterologie ruské klasiky proti syžetovosti raného sovětského období, brutalita válečné reality kontra nostalgie literatury emigrace apod.). Právě toto je aspekt, jímž kniha Iriny Kalusové přesahuje prostor dnešního Ruska. Sám bych tento spor vyjádřený různými autory neviděl tak ostře, smysl bych hledal v nacházení styčných bodů a obrušování hran, jak se o to autorka úspěšně pokusila právě v úvaze o Puškinovi a jeho pojetí umění. Faktem však zůstává, že umění a literatura jsou - at́ chceme nebo nechceme - reflexí skutečnosti a vnitřní rozvrácenost dnešního světa se $\mathrm{v}$ literatuře nemůže neprojevit. Na druhé straně právě literatura může být tím scelujícím, léčebným nástrojem, ale jelikož je její role širší a bohatší, nemůže své působení zúžit jen takto utilitárně. $\mathrm{K}$ tomu jsou však nutné osobnosti a těch se dnes nedostává nikde, tedy ani v literatuře.

Ivo Pospišil

\section{Literatura:}

KALUS, I. (2017): Sovremennaja russkaja literatura: stat'ji, èsse, interv'ju. Moskva.

PAVLOV, J. M. (2010): Kritika XX-XXI vekov: Literaturnyje portrety, sta'tji, recenzii. Moskva.

POSPÍŠIL, I. (1983): Nový Valentin Rasputin: rozcestí únavy a oživení. Světová literatura, 1983 , č. 11, s. 165-168.

POSPÍŠIL, I. (1984): Jak se kalila ocel jako hraniční literární text. Československá rusistika, 1984, č. 3, s. 109-113.

POSPÍŠIL, I. (1985a): Na nové cestě (V. Rasputin: Požar, 1985). Kmen, 1985, č. 41, s. VIII. POSPÍŠIL, I. (1985b): Okrajové a hraniční žánry v sovětské próze. Literární měsíčník, 1985, č. 2, s. 139-140.

POSPÍŠIL, I. (1999): Na výspě Evropy. Skici a meditace k 2oo. výročí narození A. S. Puškina. Brno.

POSPÍŠIL, I. (2002a): furij Bondarev a jeho Bermudský trojúhelník (Recenze s ukázkami). Alternativa Plus roč. VI, 2002, č. 3-4, s. 38-43.

POSPÍŠIL, I. (2002b): Žánrová struktura a emblematičnost apokalyptického románu furije Bondareva Bermudský trojúhelník a souvislosti. Slavica litteraria, 2002, č. $\mathrm{X}_{5}$, s. 53-62.

POSPÍŠIL, I. (2003): Jazyk literárního díla jako axiologický nástroj: román Jurije Bondareva Bermudský trojúhelník (K životnímu jubileu prof. fána Doruly). In: 
ŽEŇUCH, P. (ed.): Život slova v dejinách a jazykových vztahoch. Na sedemdesiatiny profesora Jána Dorulu. Bratislava, s. 265-278.

POSPÍŠIL, I. (2008a): Diachronní dimenze ruského literárního textu (Puškin - Bondarev -

Grjakalov). In: LEPILOVÁ, K. a kol.: Text a kontext. Brno, s. 86-107.

POSPÍŠIL, I. (2008b): Konzervativní rezistence jako součást literárního vývoje. Slavica litteraria, roč. 11, 2008, č. 2, s. 19-28.

POSPÍŠIL, I. (2008c): Tradiční a konzervativní hodnoty v literatuře konce zo. a počátku 21. století. In: KERULOVÁ, M. (ed.): Slovo - obraz - zvuk I. Literárnovedné štúdie. Nitra, s. 91-102.

POSPÍŠIL, I. (2009): Ponorná řeka memoárů na rozcestí. In: PAVERA, L. a kol.: Metamorfózy gatunków w kontekście środkoeuropejskim. Žánrové metamorfózy v středoevropském kontextu, sv. IV. Praha, s. 233-244.

POSPÍŠIL, I. (2010): (Zdravě?) konzervativní pojetí ruské literatury 2o. století (Kremencov Leonid Pavlovič: Russkaja literatura v XX veke. Obretenija i utraty. Učebnoje posobije. Vtoroje izdanije. Izdatel'stvo «Flinta», Izdatel'stvo «Nauka», Moskva 2oo8). Novaja rusistika, roč. 3, 2010, č. 2, s. 101-103.

POSPÍŠIL, I. (2015): Česká a slovenská próza dneška a politika: hraniční žánry (Několik př́kladů, kritických/teoretických poznámek a pokus o typologii). In: POSPÍšIL, I., PRZYBYLSKI, M., ŠAUR, J. a kol.: Slovanské literatury a jazyky v objetí politiky (20. století). Brno, s. 13-33.

POSPÍŠIL, I. (2016): Kvázimemoáry jako mentální signál (české a slovenské př́klady). In: POSPÍŠIL, I. (ed.): Poetika prózy v česko-slovenských souvislostech. Brno, s. 169-178. POSPÍŠIL, I. (2018): Valentin Rasputin glazami čechov (Portret i vokrug: neskolko štrichov). Stephanos, 2018, č. 1, s. 194-199.

Russkij literaturnyj žurnal Parus. (2018). <http://parus.ruspole.info/>. [online]. [cit. 8. 9. 2018].

SERAFIMOVA, V. D. (2013): Poetika prozy L. I. Borodina: dialog s kulturnym prostranstvom. Moskva.

https://doi.org/10.5817/NR2018-2-10

\section{Sborník k příležitosti XVI. mezinárodního kongresu slavistů}

POSPÍŠIL, I., ZELENKA, M., PAUČOVÁ, L. (eds): Česká slavistika 2018. Brno: Česká asociace slavistů, Jan Sojnek - Galium, 2018. ISBN 978-80-88296-oo-3.

Sborník vychází péčí České asociace slavistů ve spolupráci se Slavistickou společností Franka Wollmana a přináší příspěvky, které byly prezentovány na XVI. 